International Journal of Instruction e-ISSN: $1308-1470 \bullet w w w . e-i j i . n e t$

Article submission code: 20201226082554

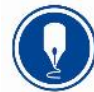

January $2022 \bullet$ Vol.15, No.1

p-ISSN: 1694-609X

pp. 527-546

Received: $26 / 12 / 2020$

Revision: $12 / 07 / 2021$
Accepted: 07/08/2021

OnlineFirst: 08/11/2021

\title{
Exploring the Effect of Digital Literacy Skill and Learning Style of Students on Their Meta-Cognitive Strategies in Listening
}

\author{
Arono \\ University of Bengkulu, Indonesia, arono@unib.ac.id \\ Safnil Arsyad \\ University of Bengkulu, Indonesia, safnil@unib.ac.id \\ Syahriman \\ University of Bengkulu, Indonesia, syahriman@ @nib.ac.id \\ Nadrah \\ State Islamic Istitute of Bengkulu, Indonesia,nadrahada@ gmail.com

\section{Ade Sissca Villia} \\ Poltikes Kemenkes Bengkulu, Indonesia, villiaadesissca@gmail.com
}

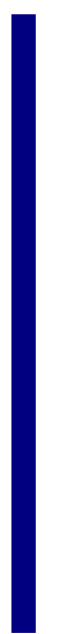

This study investigates the most dominant factors influencing Indonesian students' listening meta-cognitive strategies. The interaction of digital literacy skills research instruments and learning styles can improve the students' meta-cognitive strategies in listening skills. The role of digital literacy skills research instruments and learning styles is to enhance students' listening meta-cognitive strategies with a total sample of 242. This study uses quantitative research by applying the ex-postfacto method. Analysis of research data using descriptive and inferential statistics with a linear regression test. The results demonstrate that the pupils' digital literacy skills had the most dominant impact. The regression results disclosed that the Rvalue of the influence of the literacy variable on the meta-cognitive listening strategy was 0.468 , meaning that it had an effect of $46.8 \%$, while the learning style was only $19.20 \%$. The interaction between digital literacy skills and learning styles could improve the students' meta-cognitive listening strategies, approximately by $50.40 \%$. Digital literacy skills and learning styles have a positive role in improving students' meta-cognitive listening strategies. A student's meta-cognitive listening technique improves as his or her digital literacy skills and learning style improves.

Keywords: digital literacy skill, learning style, meta-cognitive strategies in listening, learning, listening

\section{INTRODUCTION}

The COVID 19 outbreak has brought changes in the world in all aspects of life, including education, particularly in learning using technology platforms from primary

Citation: Arono., Arsyad, S., Syahriman., Nadrah., \& Villia, A. S. (2022). Exploring the effect of digital literacy skill and learning style of students on their meta-cognitive strategies in listening. International Journal of Instruction, 15(1), 527-546. https://doi.org/10.29333/iji.2022.15130a 
school to college levels. Consequently, various online media are carried out by teachers, including zoom meeting, You Tube, television, radio, skype, google classroom, social media, or other online pages. This situation will surely have an impact on kids' digital skill competence so that the teacher's role is crucial in determining the mastery of digital literacy skills in students, especially in language learning. It is also emphasized in research conducted by Akayoğlu et al. (2020) on pre-service teacher students. They discovered that lecturers, as educators, play a critical role in development of digital literacy in tertiary institutions.

Students' learning styles will be affected by digital expertise in learning. Frequent use of digital technology will make students' digital knowledge better. Learning is previously carried out at schools and dominated by teachers in utilizing digital learning. However, the students and teachers have actively used digital media to accommodate their learning since the pandemic. It results in variations and increases in students learning styles to be more complex and innovative (Zacharis, 2011). The results of experimental research conducted by Dunn et al. (2001) on the students' learning styles show that the students' learning styles depend on the educational interventions that are beneficial for their academic achievement.

Wehrwein (2006) found in his research that learning styles were influenced by gender. Although gender in some studies still has limited influence with regard to online learning and learning styles (Santovec, 2002; Waldeck et al., 2001; Yu et al., 2001). Different things were done by Ames (2003); Gould and Caswell (2006) found significant gender differences in the nonlinear and emotional thinking subscales that women are more likely to encounter than men. Previous study said that gender is one of the characteristics to differentiate between individual learning styles, in addition to academic achievement, age, culture, analytical processes, and creativity (DePaula, 2002; Dunn et al., 2001; Hlawaty, 2002; Honigsfeld, 2000, 2001). That means that gender differences have an influence on learning styles even though they are only limited. Arsyad (2018) suggests that most high school students in Bengkulu, Indonesia, have a visual learning style regardless of gender differences. In this study, researchers did not see gender differences even though the study sample was more dominant for women than men $(80.17 \%$ women). This study examines learning styles together with digital literacy skills on the meta-cognitive strategy of listening to students.

One of the digital media used by the students is audio-visual, which makes learning more exciting. The main thing that plays a role in using this digital aspect is the listening ability through audio and listening with audio-visual. However, this is not necessarily just the ability to listen, but how the students' listening strategies result in good listening comprehension so that learning can be well achieved. It has been proven by the research conducted by Mahdavi and Miri (2016) used process-based and product-based education to improve listening comprehension and meta-cognitive awareness when studying the effect of meta-cognitive awareness. Their results indicated that listening comprehension and meta-cognitive awareness, the process-based group outperformed the product-based group substantially. Furthermore, a dialogic micro-genetic examination of the interactions of process-based groups provides some evidence of how 
students select meta-cognitive awareness. One of the factors mentioned above that learning style has a significant impact on EFL learners' various language skills. That is the reason why English learners with divergent styles have their own strengths and weaknesses (Reid, 1995a). Thus, each individual possesses different language skills (writing, speaking, reading, and listening) depending on their LS. (Ruiz-Funes, 2015; Sahragard \& Mallahi, 2014; Soureshjani \& Naseri, 2012). On the other hand, listening skill is one of the most complicated skill for most English as Foreign Language (EFL) learners so that they need to find the ways to solve the problems (Graham, 2006). Thus, different learning situations lead to various performances of LS (Ehrman et al., 2003). Therefore, These LS variations must be taken into account by EFL / English as a Second Language (ESL) teachers in order for students with various learning preferences to have a positive learning experience (Chang, 2005). Recent research in the subject of listening to a second language (L2, for short) has primarily focused on the impacts of MLSA or its interaction with other EFL-related characteristics (Bozorgian, 2014; Cross, 2011; Latifi et al., 2014; Rahimi \& Katal, 2013; Vandergrift \& Goh., 2012; Vandergrift et al., 2006).

Tutunis (2001) suggests that learners' learning styles need to be considered in influencing meta-cognitive listening strategies. Learning styles can improve metacognitive listening strategies (Jowkar, 2012). Some studies have investigated a relationship between learning styles and strategy preferences. For example, Ahmadi and Yamini (2003) looked at the extent to which L2 learners had different learning styles using listening strategies. They found that field-independent listeners (listeners who can separate detail from the surrounding context) used meta-cognitive, memory, and cognitive strategies more frequently. Conversely, field-dependent listeners (listeners who couldn't distinguish the details from other surrounding information) used social more strategies. Similarly, Bidabadi and Yamat (2010) explored the relationship between L2 learners' perceptual learning styles and their chosen strategies. The results showed a significant positive relationship between communicative learning strategy and the implementation of meta-cognitive, cognitive, and socio-affective listening strategies. Communicative learners also tend to learn using top-down strategies. Jowkar's (2012) study further verified the significant relationship between learners' learning styles and their use of strategies.

Regarding learning styles, learning media, in this case, digital / ICT literacy also affects students' meta-cognitive listening strategies, such as research conducted by Roussel (2011) using a computer-assisted method to track the use of L2 listening strategies. The relationship between gender differences and strategy use has also been investigated extensively, along with these factors. The results (Smidt \& Hegelheimer, 2004) show apparent discrepancies between male and female L2 learners in terms of strategy. Women tend to use learning strategies more often than men do.

Based on the problems and theoretical studies above, this research aim is to find out the most dominant factors that influence the students' meta-cognitive strategies in listening skills, to know the interaction of digital literacy research instruments and learning styles that can improve the students' meta-cognitive strategies in listening and to know the role 
of research instruments. Digital literacy skills and learning styles to improve students' meta-cognitive listening strategies. The study questions are as follows, in accordance with the research objectives: What is the most dominant factor that causes the increase in meta-cognitive strategies in listening to students? To what extent can the interaction of digital literacy skills research instruments and learning styles work together to improve students' meta-cognitive strategies in listening? What is the role of digital literacy skills research instruments and learning styles in efforts to improve students' meta-cognitive strategies in listening?

\section{Theoretical Background}

\section{Digital Literacy Skill}

In a digital network context, digital literacy is a sophisticated and interconnected structure between sub-disciplines consisting of skills, ethics, knowledge, and creative output (Calvani et al., 2008). The above definition of literacy focuses on digital literacy as a tool, whereas normative media education literacy focuses on disciplines and needs, such as language teaching, where digital literacy is concerned with language, information, relationships, and redesign (Dudeney \& Hockly, 2016). Print, text, hypertext, visual multimedia, game, cellular, code, and technology are all linked to language literacy. Search, information, tagging personal, network, participatory, cultural and intercultural are all literacy topics covered in this section. Remix literacy is linked to redesign. It follows Gapski's opinion of splitting digital literacy into two categories, "instrumental-technology" and "normative media education," with the function and pedagogical aims of "instrumental-technology" and "normative media education," respectively (Gapski, 2007). It is separated into three competencies: (a) message interpretation; (b) message selection; and (c) message delivery. The aims and measurement of functional, cognitive, and ethical abilities are based on these competences.

Calvani et al. (2009) concluded that digital literacy is a combination of power and skill that cannot be quantified, but that is more flexible in analysing, selecting, information, and critically evaluating data, while raising awareness of individual responsibility and mutual respect for rights and obligations. It demonstrates that digital literacy does not have to be a sequential process or rooted just in specific tasks. Digital literacy, according to Aviram and Eshet-Alkalai (2006), is the combination of five distinct but connected literacy skills: (a) reproductive literacy; (b) photo-visual literacy; (c) branching literacy; (d) information literacy; (e) socio-emotional literacy. These abilities are offered as culturally distinct epistemological manifestations, with a range of abilities that create various learning methods and personality types. Based on the foregoing, digital literacy abilities are linked to understanding digital practises; looking for and using information; endogenous motivation; creating information; exogenous motivation; operating digital devices; searching, selecting, and creating information; digital engagement; supporting learning practices (Yazon, et al., 2019; Soomro, et al., 2018). 


\section{Learning Style}

A person's learning style is how he or she concentrates, processes, internalizes, and remembers new and difficult information or academic skills. A person's style often varies according to age, level of achievement, culture, global versus analytical, processing preferences, and gender (Shaughnessy, 1998). Three types of learning styles classified based on linguists' teaching (Banner \& Rainer, 2000; Oxford, 2003), namely 'visual,' 'auditory' and 'kinesthetic.' It is also confirmed by Kolb (2000) that there are four modes. The lessons included in the Kolb Learning Style Inventory are concrete experiences (CE, feelings), reflective observation (RO, watching), abstract conceptualization (AC, thinking), and active experiments (AC, doing). Individuals have diverse learning styles, according to Reid (1995a), and as a result, they have varied natural ways, habits, and preferences for acquiring, processing, and storing new information and abilities. Reid (1995a) created a perceptual learning style questionnaire to assist students in determining what helps them learn by identifying their prefered learning style. Based on Reid statement (1995a), visual learners learn through their eyes. Others learn with their ears (auditory learners). Furthermore, some individuals prefer to learn by experience (kinesthetic learners). Some people may prefer to work individually, while others may be comfortable with group work.

In this regard, the result of a questionnaire constructed by Reid (1995b) indicated that ESL participants preferred tactile and kinesthetic learning styles over audio and visual learning styles. This study was replicated by Stebbins (1995) and discovered the same results. For this study, Reid's approach was adopted for several reasons. First, the approach relies on a sensory modality of learning styles. Second, it aims to investigate individual LS and promote active learning to the students by encouraging them to be involved actively during the learning process. The results could be achieved when the teacher knows how to reach every student. Similarly, Fathi and Hamidizadeh (2019) suggests that the teachers need to encourage the students to have a good learning strategy.

\section{Meta-cogitive Strategies Listening}

The learning strategy in listening consists of two parts, namely meta-cognitive and cognitive. According to Oxford (2011), meta-cognitive strategies are considered as "construction managers," whose tasks are to focus, plan, acquire resources, organize, coordinate, monitor, and evaluate a person's L2 process of knowledge. Vandergrift et al. (2006), developed the Meta-cognitive Awareness Listening Questionnaire (MALQ) to examine L2 listeners' meta-cognitive awareness and their perceptions about using listening strategies, Sort metacognitive strategies into the following five categories: (1) planning-evaluation, (2) directed attention, (3) people knowledge, (4) mental translation, and (5) problem-solving. To understand the target language and accomplish tasks, metacognitive methods require a high level of cognitive processing. It allows students for task-based learning to assist learners in developing their meta-cognitive knowledge about listening (Vandergrift and Goh, 2012). Meta-cognitive strategies are techniques that are useful in improving listening skills. It involves a person's knowledge/cognitive 
processes, active monitoring, consequent regulation, and unification (Flavell, 1979). Metacognition is also defined as awareness and control of one's cognition, consisting of two different components: knowledge and regulation (Wenden, 1998).

The meta-cognitive listening strategies are (1) Planning (Preparing mentally and emotionally for the listening task): reviewing the content and practicing potential words. (2) Attention directed (attention monitoring and avoiding distraction): concentrate fully and continue listening despite difficulties. (3) Selective attention (determine listening in advance for certain aspects of the input) Determine in advance to listen familiar content words; notice how information is structured (e.g., discourse markers); pay attention to repetition; notice intonation features (e.g., stopping or weakening and increasing pitch). (4) Monitoring (checking/ensuring understanding while listening): confirm the understanding that has occurred; identify words or ideas not understood; check the current interpretation with the context of the message; check recent interpretations with prior knowledge. (5) Evaluation (interpretation fits accuracy, completeness, and acceptability after listening): check interpretation against external sources; check interpretation using prior knowledge; according to interpretation according to the context of the message (Goh, 2002; Vandergrift, 1999).

\section{METHOD}

\section{Research Design}

This research is a quantitative study using the ex-post-facto method. Descriptive quantitative analysis describes existing phenomena by characterising the characteristics of students using numbers in quantity and quality. Ex-post-facto is used to determine the causal relationship between dependent and independent variables. Research on causal relationships is carried out on programs, activities, or events that have taken place or have occurred (Howell, 2011). The dependent variable, namely the meta-cognitive listening strategy, while the independent variable, namely digital literacy skills and learning styles. This research examines the effect of digital literacy skills and learning styles on students' listening meta-cognitive strategies. A literature review shows many studies influence of learning styles on metacognition strategies on different factors. Few studies have examined the influence between variables affecting listening meta-cognitive strategies, including digital literacy skills. This data is considered to represent the Indonesian state which is referred to as an archipelago and from different regions, namely in the developed capital city (Java) and in the province or in the region (Sumatra).

\section{Participants and Context}

Participants in this study were Indonesian Language Education students at state universities in Indonesia, namely two universities in rural areas on the island of Sumatra and two universities in urban areas on Java. Students are determined based on multistage area random sampling, namely semester VI students. It is because students of semester VI are considered to have taken language skills courses, students who have entered the last semester or will prepare a thesis proposal and have completed $80 \%$ of their lectures. Different universities were chosen since Indonesia is an archipelago which is considered 
to represent the islands in Indonesia. The data were gained from four state universities in Sumatra (Univerisity of Bengkulu and Padang State University) and Java (Syarif Hidayatullah State Islamic University Jakarta and University of Pakuan), with a total sample of 242 .

The Likert rating scale with the following criteria interval is obtained as follows:

Table 1

Criteria for each dimension's capability

\begin{tabular}{ll}
\hline Internal & Creteria \\
\hline $1.00-1.80$ & Very Low \\
\hline $1.81-2.60$ & Less \\
\hline $2.61-3.40$ & Moderate \\
\hline $3.41-4.20$ & High \\
\hline $4.21-5.00$ & Very High \\
\hline
\end{tabular}

\section{Data Collection Procedures}

Data were collected using closed instruments and several open questions. There are four main reasons why instruments are performed with closed instruments. Firstly, in order to be better reach all students in urban and rural areas with large sample. Secondly, number of instruments developed in the three research variables' indicators makes it impossible to ask questions. Thirdly, this instrument is considered valid since it has been developed by researchers and has been carried out in several studies so that researchers deal with it according to Indonesian language teaching. Fourthly, this instrument was developed with an online model using Google Form for all students whose samples had been determined.

\section{Instruments}

Three questionnaires were applied to conduct the research: the digital literacy skills questionnaire (Soomro et al., 2018; Yazon et al., 2019); learning styles (Reid, 1995a); meta-cogitive strategies listening (Vandergrift et al., 2006). Participants were asked to fill out a digital literacy ability questionnaire totalling 12 indicators with 75 statements, a learning style questionnaire with six indicators with 30 statements, and a meta-cognitive strategy listening to five indicators with 21 statements.

\section{Data Analysis}

The data analysis of the research findings was done in two stages: descriptive statistical analysis and financial-statistical analysis. The descriptive analysis described students' digital literacy skills, learning styles, and listening to cognitive strategies. In describing the students' skills in each dimension, the following equation is implemented.

Interval $=\frac{U-L}{I}$

Information:

$\begin{array}{ll}\mathrm{U} & =\text { Highest answer score } \\ \mathrm{L} & =\text { Lowest answer score } \\ \mathrm{I} & =\text { Number of interval classes (Sugiyono, 2010). }\end{array}$ 
The data from the research results were utilized to answer the research questions using inferential statistical analysis with multiple linear regression analysis. The mathematical equation which states the relationship between the research variables is written as follows.

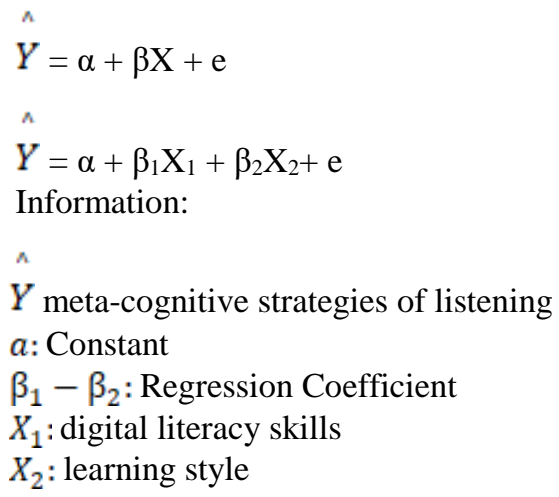

\section{FINDINGS}

The research results are described based on each research variable. Based on 11 indicators, literacy skills with an average of 3.56 (level 4) are categorized as high. High digital literacy indicators are supporting learning practices (4.11), using computers and the internet (3.91), engaging using digital (3.89), searching, selecting, and evaluating information (3.81), exogenous motivation (3.67), endogenous motivation (3.61), operating digital devices (3.59), looking for information (3.44). The sufficient digital literacy skills, namely using information (3.28), making information (3.09), and understanding digital practice (3.08). It means that students' digital literacy skills in understanding, using, and making digital literacy need to be improved. Then, seeking, motivating, operating, engaging, and supporting digital literacy by working from home when COVID 19 provides students' positive digital literacy skills.

Students' learning styles of the six learning styles are almost balanced. It has been proven from the categories on each learning style with a high category and a high average (3.90). As for each learning style category, namely kinesthetic (4.11), auditory (4.10), group (3.92), tactile (3.87), visual (3.84), and individual (3.58). It means that the conditions for the COVID 19 pandemic still want a balance in learning styles. It is not only dominated by visual or individual or auditory aspects, but students still need the aesthetic, group, and tactile aspects in their learning. Of the 242 respondents, $80.17 \%$ were women (194 students), while $19.83 \%$ were men (48 students). During the pandemic era, learning from home has not significantly changed the way students learn.

The students' meta-cognitive listening strategy has a high average of the five indicators of their meta-cognitive listening strategy (3.99). The details of each indicator in the strategy of listening to students' meta-cognitive are direct attention (4.69), problemsolving (3.96), mental translation (3.86), planning/evaluation (3.77), and person knowledge (3.71). It indicates that students' listening activity with high technology, 
especially in the aspect of very high directed attention. It indicates that listening to students with learning from the home of the COVID 19 pandemic era has become high in their meta-cognitive listening strategy.

Research question 1: The most dominant factor that causes the increase in metacognitive strategies in listening to students.

Many factors can influence the meta-cognitive strategy of listening to students, including attitudes, knowledge, education, gender, culture, and social skills, digital literacy skills, and student learning styles. However, this study scrutinized only the factors of students 'digital literacy abilities and learning styles that could influence students' meta-cognitive listening strategies. Of the two independent variables, the explanation in the regression test of digital literacy abilities and student learning styles on students' listening metacognitive strategies can be seen from the explanation of the regression test below.

Table 2

Regression analysis results

\begin{tabular}{lllll}
\hline No. & Independent Variable & Result & & Probability \\
\hline & & Coefficient & t-stat & \\
\hline & a & & & \\
& $Y=\mathrm{a}+\beta_{1} \mathrm{X}+\mathrm{e}$ & & & 0.000 \\
\hline $1 \quad$ Digital literacy skills & 0,215 & 14.534 & \\
\hline & Constanta (a) & 22.96 & & \\
\hline & R-Square & 0.468 & & \\
\hline & F-Statistic & 211,39 & & \\
\hline & Probability (F-statistic) & 0.000 & & \\
\hline
\end{tabular}

a.

Table 2. above shows that the regression equation: $Y=22.96+0.215 \mathrm{X}$. The regression equation interpretation means that the constant value (a) is 22.96 , indicating that if the students 'literacy skills do not increase, then the students' meta-cognitive abilities are constant at 22.96. The regression coefficient of the literacy ability variable (b) of 0.215 shows a positive relationship that if students' digital literacy skills are higher, then metacognitive abilities will increase. The coefficient of determination (R2) is 0.468 , that means the statistical digital literacy skills of $46.8 \%$ can explain the variation in the increase or decrease in meta-cognitive abilities. In comparison, the remaining $53.20 \%$ is influenced by other factors that are not examined. It implies that there is an impact on students' literacy skills on meta-cognitive abilities. The effect given is positive and is $46.80 \%$. 
Table 3

Regression analysis results

\begin{tabular}{lllll}
\hline No. & Independent Variable & Result & & Probability \\
\hline & & Coeff & t-stat & \\
& & & & \\
& $Y=\mathrm{a}+\beta_{2} \mathrm{X}+\mathrm{e}$ & & & 0.000 \\
\hline 2 & Learning style & 0.481 & 7.54 & \\
\hline Konstanta (a) & 23.81 & & \\
\hline & R-Square & 0.192 & & \\
\hline & F-Statistic & 56.99 & & \\
\hline
\end{tabular}

Table 3 shows that the regression equation: $Y=23.81+0.418 \mathrm{X}$. The regression equation interpretation means that the constant value (a) is 23.81 , indicating that if the student's learning style does not improve, then the student's meta-cognitive ability is constant at 23.81. The regression coefficient of the digital literacy skills variable (b) of 0.481 indicates a positive relationship that if the student's learning style is getting better, then the meta-cognitive ability will increase. The coefficient of determination $(R 2)$ is 0.192 , that means the variation in the increase or decrease in listening meta-cognitive ability can be explained by the statistical learning style of $19.20 \%$. At the same time, the remaining $80.80 \%$ is influenced by other factors not examined. It means there is an influence of students' learning styles on listening meta-cognitive strategies. The effect is positive and is $19.20 \%$.

Research question 2: Interaction of digital literacy research instruments and learning styles to improve students' meta-cognitive listening strategies.

The interaction of digital literacy research instruments and learning styles can work together to improve students' meta-cognitive listening strategies. Simultaneously, this research instrument's interaction with the meta-cognitive strategy in listening to students in the output of the regression test results from the following table.

Table 4

Simultaneous of regression analysis results

\begin{tabular}{|c|c|c|c|c|}
\hline No. & Independent Variable & \multicolumn{2}{|l|}{ Result } & Probability \\
\hline & & Coeff & t-stat & \\
\hline & a & & & \\
\hline & $Y=\mathrm{a}+\beta_{1} \mathrm{X}_{1}+\beta_{2} \mathrm{X}_{2}+\mathrm{e}$ & & & \\
\hline 3 & Digital literacy skills & 0.190 & 12.28 & 0.000 \\
\hline & Learning style & 0.226 & 4.17 & 0.000 \\
\hline & Constanta (a) & 3.086 & & \\
\hline & R-Square & 0.504 & & \\
\hline & F-Statistic & 121.66 & & \\
\hline & Probability (F-statistic) & 0.000 & & \\
\hline
\end{tabular}


Based on table 4. above shows that the regression equation: Regression equation: $Y=$ $3.086+0.190 \mathrm{X}_{1}+0,226 \mathrm{X}_{2}$. The regression equation interpretation means that the constant value (a) of 3.06 indicates that if digital literacy skills and learning styles do not change, the students' meta-cognitive listening strategy will be constant, which is 3.06. The coefficient of determination $(R 2)$ is 0.504 , that means the variation in the increase or decrease in listening meta-cognitive strategies can be explained by digital literacy skills and learning styles simultaneously by $50.40 \%$. \%. It indicates that simultaneously the two variables, namely digital literacy skills and learning styles, affect the students 'listening meta-cognitive strategy. That means that the interaction between digital literacy skills and learning styles can improve students' listening meta-cognitive strategies, which reached $50.40 \%$. It means that an increase compared to the effect partially.

Research question 3: The role of research instruments for digital literacy skills and learning styles in efforts to improve students' listening meta-cognitive strategies.

The role of research instruments for digital literacy skills and learning styles in improving students' listening meta-cognitive strategies is described as follows:

Table 5

Recapitulation of the regression calculation results

\begin{tabular}{lll}
\hline Relationship & Score R Square & Great Influence \\
\hline $\begin{array}{l}\text { Digital literacy skills } \\
* \text { Meta-cognitive strategies in listening }\end{array}$ & 0.468 & $46.80 \%$ \\
\hline $\begin{array}{l}\text { Learning styles } \\
* \text { Meta-cognitive strategies in listening }\end{array}$ & 0.192 & $19.20 \%$ \\
\hline $\begin{array}{l}\text { Digital literacy skills and learning styles. } \\
\text { * Meta-cognitive strategies in listening }\end{array}$ & 0.504 & $50.40 \%$ \\
\hline
\end{tabular}

From Table 5, each research instrument has a role in improving students' meta-cognitive strategies in listening. In this regard, the ability of digital literacy to meta-cognitive listening strategies has a role of $46.80 \%$. The role of learning styles in listening to students' meta-cognitive strategy was $19.20 \%$. Together, digital literacy skills and learning styles on listening meta-cognitive strategies have a role of $50.40 \%$. It means that digital literacy and learning styles have a positive role in improving students' listening meta-cognitive strategies. The higher the digital literacy and learning style of a student, the higher the meta-cognitive strategy of listening to the student. This result is based on the regression test obtained by a positive $t$ value and the positive regression equation's coefficient.

\section{DISCUSSION}

The COVID 19 pandemic in Indonesia is currently impacting all communities in different fields, such as social, education, economic, and tourism. In tertiary education, there have been many changes in the students' paradigm on network learning, from those who don't know to know and be skilled in applying technology. Likewise, with student 
learning styles, usually carried out in groups, aesthetics, touch, with the COVID 19 learning from home, there are more visual, audiovisual, and individual styles. It is experienced by approximately three months of students learning from home interacting with lecturers using several applications such as classrooms, video conference, telephone or live chat, zoom or via WhatsApp groups, and other e-learning. This is an educational innovation that addresses the issues of a lack of diverse learning resources. The success of a learning medium, on the other hand, is determined by the characteristics of its students. According to Nakayama (2007), all e-learning literature indicates that not all students will be successful in online learning. It is due to the learning environment and student characteristics, in this case, digital literacy and student learning styles towards listening meta-cognitive strategies can also determine student learning success.

This study indicates that the conditions of the COVID 19 pandemic learning from home can improve students' digital literacy skills. It can be seen from the students' literacy skills result in the high category (3.56). Students' digital literacy skills are dominated by aspects of supporting learning practices, using computers and the internet, and engaging in using digital, selecting, searching, and evaluating information. It indicates that the rapid change in the communication and media industry has increased creative development in teaching and learning approaches to media's influence on society. (Cohen \& Mihailidis, 2013). It means that students learn intelligent media consumption and production skills, critical evaluation and analysis of media messages, and participation in local, national, and global dialogue (Frechette, 2002; Gaines, 2010; Hobbs, 2010, 2011; Tisdell, 2008). Lecturers should take advantage of this opportunity to integrate into online classes in both formal and informal learning through e-learning or other social media.

Likewise, the students' learning styles can balance the learning variations by learning from home, which previously learning in class or face-to-face, namely in the high category (3.90). Students are more dominant in using kinaesthetic and auditory learning styles. It indicated that learning from home is still not able to replace the dominant learning styles that have been carried out in class, namely kinaesthetic and auditory. The kinaesthetic learning style prioritizes doing, experimenting, and participating. Students still need and want to learn directly or face-to-face with the dominant kinaesthetic and auditory learning styles. Reid (1995b) also found that ESL participants preferred kinaesthetic learning styles to other learning styles. This study was replicated by Stebbins (1995), who found the same results. Female learning styles dominate this learning style because the respondents in this study were 194 female respondents $(80.17 \%)$, while 48 were male (19.83\%). According to Dunn et al. (2001) opinion, women are more dominant in listening or audio learning styles. Students in the auditory learning style prioritize more understanding, being told directly and learning it better, remembering what is heard in class, when learning to describe it, and listening to someone better. It means that learning styles have a positive impact on learning activities quality for EFL students (Reza et al., 2019). However, Malacapay (2019) found that the students' demographic profile and academic accomplishment do not influence the learning styles. 
The high level of digital literacy skills and student learning styles will impact the students' meta-cognitive strategy in listening, which is much improved, namely in the high category (3.99). The meta-cognitive strategy in listening is dominated by the aspects of directed attention and problem-solving. It means that students have used good listening strategies in their learning. Students are more focused or concentrated, using words that are already understood, comparing what is understood, using knowledge or experience, and quickly adjusting interpretations. This result is reinforced by the study conducted by Bozorgian (2014); Rahimirad and Shams (2015); Maftoon and Alamdari (2016) showed that affter using the students' meta-cognitive method in listening, there was a considerable rise in their meta-cognitive awareness.

The factor that had the most dominant influence on improving the students 'metacognitive strategies in listening was the students' literacy skills. It is based on the regression test results for the value of $\mathrm{R}$ square, the effect of the literacy variable on cognitive strategies is 0.468 , which means it has an impact of $46.80 \%$. \%, while the learning style was only $19.20 \%$. It is in line with the research results conducted by Kong (2014), which states that students have statistically significant growth in information literacy competencies and critical thinking skills. Likewise, semi-structured interviews found that students and teachers felt the effectiveness of pedagogical designs positively in digital classrooms in supporting the development of information literacy competencies and critical thinking skills. However, learning styles are not dominant compared to digital literacy skills. The learning styles carried out during the COVID 19 pandemic are not appropriate to students' learning styles due to conditions and circumstances. They are "forced" to learn from home. It is reinforced in the results of Zapalska and Brozik (2015) research that online learning achievement can be improved by providing instruction in a way that suits each student's learning style. Even though a particular student learns in the best possible way, he or she must be exposed to a variety of learning experiences to become a more flexible online learner.

Learning from home with pandemic conditions can be maximally utilized by students in exploring and increasing their mastery of digital literacy and trying something new with a variety of learning styles to gain insight and understanding of meta-cognitive strategies to better listen to students. It is in line with the research results that the interaction of the two variables between digital literacy skills and learning styles can improve students' meta-cognitive strategies in listening, which reached up to $50.40 \%$. It means an increase compared to the effect partially. It is also reinforced by the research results from Zarrabi (2017), which found a statistically significant relationship between student style and awareness of EFL students' meta-cognitive listening strategies. In other words, each type of learner differs in their level of meta-cognitive listening awareness. Auditory students show a significant difference in mean scores on MALQ compared to other students' styles.

The most dominant factor in this research is students' digital literacy skills. It is based on the regression test results for the value of $\mathrm{R}$ square, the effect of the variable digital literacy ability on the meta-cognitive listening strategy of 0.468 , which means that it has 46.8\%. Meanwhile, the learning style was only 19.2\%. Digital literacy skills and 
learning styles have a psychological role in improving students' meta-cognitive strategies in listening. The higher the digital literacy and learning style of a student, the higher the meta-cognitive strategy of listening to the student. It is based on the regression test obtained by a positive $t$ value and the positive regression equation's coefficient. This right is also reinforced by the research results from Yazon et al. (2019) that there is a strong and significant relationship between digital literacy, increased understanding, discovery, use, and creation of information using digital technology ability. Likewise, digital competence has a significant correlation with productivity. With the increase in knowledge, skills, and attitudes to work, live, learn in a knowledge society, a significant increase also occurs in the ability to produce.

The interaction between digital literacy skills and learning styles can improve metacognitive strategies for listening to students, either individually or collectively. This is supported by some studies that have shown that increasing students' meta-cognitive awareness in listening through strategic-based instruction and process-based approaches can foster listening understanding (Cross, 2011; Graham and Macaro, 2008; Liu and Goh, 2006; Vandergrift and Tafaghodtari, 2010; Vandergrift, 2003). Meta-cognitive awareness can also nurture students in independent listening or reading skills (Vandergrift et al., 2006; Muhid et. al., 2020). Arono (2015) argues that meta-cognitive listening strategies can improve students' critical listening skills, namely (1) effective activities, students create active, effective, and creative learning processes independently in measuring and developing in each step the listening learning model. (2) media can improve students 'critical listening skills, (3) the performance of critical listening strategies can improve students' critical listening skills. This is because learning to listen is not only an aural aspiration but also visual aspects that are integrated with multimedia (Arono, 2014).

\section{CONCLUSION AND RECOMMENDATIONS}

The COVID 19 pandemic conditions by studying from home have been able to improve digital literacy skills and student learning styles towards students' listening metacognitive strategies. Students' digital literacy skills are dominated by aspects of supporting learning practices, using computers and the internet, as well as engaging in using digital and evaluating information. In terms of learning styles, students are more dominant in using kinesthetic and auditory learning styles. Aspects of directed attention and problem-solving dominate the meta-cognitive strategy in listening to students. Students are more focused or concentrated, using words that are already understood, comparing what is understood, using knowledge or experience, and quickly adjusting interpretations. The factors that give the most dominant influence our students' literacy skills. The interaction between digital literacy skills and learning styles can enhance meta-cognitive listening strategies. Digital literacy skills and learning styles have a psychological role in efforts to improve students' meta-cognitive listening strategies. The higher the digital iteration and learning style of a student, the higher the meta-cognitive strategy of listening to the student.

Increasing the digital literacy skills and student learning styles towards students' metacognitive strategies in listening shows that students can have positive knowledge and 
insight and are good at responding to the COVID 19 pandemic by learning from home. Therefore, various online learning policies with the new normal period are expected that lecturers will maximize themselves in developing online learning tools to master their learning. Likewise, students should maximize the variety of online learning tools and learning styles to develop language skills with various online learning sources. The government or university can provide adequate facilities so that the learning process of meta-cognitive strategies in listening can run well, such as adequate free internet access.

\section{REFERENCES}

Ames, P. C. (2003). Gender and learning style interactions in students' computer attitudes. Journal of Educational Computing Research, 28(3), 231-244. https://doi.org/10.2190/M8CU-DE21-BJF1-84MN

Ahmadi, A., \& Yamini, M. (2003). Relationship between field dependence/independence and listening comprehension strategy use by female Iranian English majors. Journal of Faculty of Letters and Humanities, 46(187), 61-72. https://www.sid.ir/en/journal/ViewPaper.aspx?ID=4506

Akayoğlu, S., Satar, M., Dikilitas, K., Cirit, N. C., \& Korkmazgil, S. (2020). Digital literacy practices of Turkish pre-service EFL teachers. Australasian Journal of Educational Technology, 36(1), 85-97. https://doi.org/10.14742/ajet.4711

Arono, A. (2014). Improving student listening skill throught interactive multimedia in indonesia, Journal of Language Teaching and Research, 5(1), 63-69. https://doi.org/10.4304/jltr.5.1.63-69

Arono, A. (2015). Relationship between listening strategy performance toward critical listening ability of Indonesian students, Journal Al Talim IAIN Padang, 22(1), 81-87. http://dx.doi.org/10.15548/jt.v22il.117

Aryad, S. (2018). Student's learning style: A case study of senior high school in Bengkulu. Edulite: Journal of English Education, literature, and Culture, 3(1), 25-39. http://dx.doi.org/10.30659/e.3.1.25-39

Aviram, A., \& Eshet-Alkalai, Y. (2006). Towards a theory of digital literacy: Three scenarios for the next steps. European Journal of Open, Distance and E-Learning, 1(1), 1-28. http://www.eurodl.org/materials/contrib/2006/Aharon_Aviram.htm.

Bidabadi, F. S., \& Yamat, H. (2010). The relationship between listening strategies employed by Iranian EFL freshman university students and their learning style preferences. European Journal of Social Sciences, 16(3), 342-351. https://doi.org/10.5539/elt.v4n1p26

Bozorgian, H. (2014). The role of metacognition in the development of EFL learners' listening skill. International Journal of Listening, 28(3), 149-161. https://doi.org/10.1080/10904018.2013.861303

Calvani, A., Cartelli, A., Fini, A., \& Ranieri, M. (2008). Models and Instruments for Assessing Digital Competence at School. Journal of e-Learning and Knowledge Society, 4(3), 183-193. https://doi.org/10.20368/1971-8829/288 
Calvani, A., Fini, A., \& Ranieri, M. (2009). Assessing digital competence in secondary education - issues, models, and instruments. In M. Leaning (Ed.), Issues in Information and Media Literacy: Education, Practice and Pedagogy (pp. 153-172). Infroming Science Press. https://doi.org/10.17471/2499-4324/299

Chang, C. Y. K. (2005). Intuitive-analysis style and EFL listening strategies. Annual Review of Education, Communication and Language Sciences, 2(1), 1-19. https://research.ncl.ac.uk/media/sites/researchwebsites/arecls/kelly.htm

Cross, J. (2011). Meta-cognitive instruction for helping less-skilled listeners. English Language Teaching Journal, 65(4), 408-416. https://doi.org/10.1093/elt/ccq073

DePaula, R. (2002). Comparative analysis ofthe learning styles of Brazilian versus other adolescents. from diverse nations by age, gendez and academic achievement. Unpublished doctoral dissertation, St. John's University, New York.

Dunn, R., Thies, A. P., \& Honigsfeld, A. (2001). Synthesis ofthe Dunn and Dunn learning-style model research: Analysis from a neumpsychological perspective. New York: St. John's University, Center for the Study of Learning and Teaching Sryles

Ehrman, M. E., Leaver, B. L., \& Oxford, R. L. (2003). A brief overview of individual differences in second language learning. System, 31(3), 313-330. https://doi.org/10.1016/S0346-251X(03)00045-9

Fatih, J. \& Hamidizadeh, R. (2019). The contribution of listening strategy instruction to improving second language listening comprehension: A case of Iranian EFL learners. $\begin{array}{llll}\text { International Journal of Instruction, } & 12(2), & \text { 17-32. }\end{array}$ https://doi.org/10.29333/iji.2019.1222a

Flavell, J. H. (1979). Metacognition and cognitive monitoring: A new area of cognitive developmental inquiry. American Psychologist, 34(10), 906-911. https://doi.org/10.1037/0003-066X.34.10.906

Frechette, J. D. (2002). Developing media literacy in cyberspace: Pedagogy and critical learning for the twenty-first-century classroom. Praegar.

Gaines, E. (2010). Media literacy and semiotics. Palgrave.

Gapski, H. (2007). Some reflections on digital literacy. Proceedings of the 3rd International Workshop on Digital Literacy. (pp. 49-55). Crete, Greece: CEUR-WS.org.

Gould, T. E., \& Caswell, S. V. (2006). Stylistic learning differences between undergraduate athletic training students and educators: Gregorc mind styles. Journal of Athletic Training, 4l(1), 109-116. https:/www.ncbi.nlm.nih.gov/pmc/articles/PMC1421495/

Graham, S. (2006). Listening comprehension: The learners' perspective. System, 34(2), 165-182. https://doi.org/10.1016/j.system.2005.11.001

Graham, S., \& Macaro, E. (2008). Strategy instruction in listening for lower intermediate learners of French. Language Learning, 58(4), 747-783. https://doi.org/10.1111/j.1467-9922.2008.00478.x 
Goh, C. (2002). Learners' selfreports on comprehension and learning strategies for listening. Asian Journal of English Language Teaching, 12(1), 45-68.

Hlawaty, H. (2002). Compaintive analysis of the learning styles ofGerman versus other adolescents. from diverse nations by age, gender; and academic achievement level. Unpublished doctoral dissertation, St. John's University, New York.

Hobbs, R. (2010). Digital and media literacy: A plan of action," a white paper on the digital and media literacy recommendations of the knight commission on the information needs of communities in a democracy. The Aspen Institute.

Hobbs, R. (2011). Digital and media literacy: Connecting Culture and Classroom. Corwin Press.

Honigsfeld, A. M. (2000). The learning styles of high-achieving and creative adolescents in Hungary. Gifed and Talented International. 15(1), 39-51. https://doi.org/10.1080/15332276.2000.11672928

Honigsfeld, A. M. (2001). A comparative analysis of the learning styles of adolescents from diverse nations by age, gender, academic achievement level, and nationality. (Dcctoral dissertation, St. John's University) Dissertation Abstracts International, DAIA 62/03.p. 969.

Howell, D. C. (2011). Fundamental statistics for the behavioral sciences. Wadsworth Cengage Learning.

Jowkar, M. (2012). The relationship between perceptual learning style preferences and listening comprehension strategies of Iranian intermediate EFL learners. Academic $\begin{array}{lll}\text { Research International, } & \text { 2(2), }\end{array}$ http://www.savap.org.pk/journals/ARInt./Vol.2(2)/2012(2.2-81).pdf

Kolb, D. (2000). Facilitator's guide to learning. Hay/McBer Training Resources Group.

Kong, S. C. (2014). Developing information literacy and critical thinking skills through domain knowledge learning in digital classrooms: An experience of practicing flipped classroom strategy, Computers \& Education, 78(9), 160-173. https://doi.org/10.1016/j.compedu.2014.05.009.

Latifi, M., Tavakoli, M., \& Dabaghi, A. (2014). The effect of meta-cognitive instruction on improving listening comprehension ability of intermediate EFL learners. International Journal of Research Studies in Language Learning, 3(6), 21-33. https://doi.org/10.5861/ijrs1l.2014.679

Liu, X. L., \& Goh, C. (2006). Improving second language listening: Awareness and involvement. In T. S. C. Farrell (Ed.), Language teacher research in Asia (pp. 91-106). TESOL.

Maftoon, P., \& Alamdari, E. F. (2016). Exploring the effect of meta-cognitive strategy instruction on meta-cognitive awareness and listening performance through a processbased approach. International Journal of Listening, 34(1), 1-20. https://doi.org/10.1080/10904018.2016.1250632 
Mahdavi, N., \& Miri, M. (2016). Co-shaping meta-cognitive awareness and developing listening comprehension through process-based instruction. International Journal of Listening, 33(1), 1-18. https://doi.org/10.1080/10904018.2016.1260454

Malacapay, M. C. (2019). Differentiated instruction in relation to pupils' learning style. International Journal of Instruction, 12(4), 625-638. https://doi.org/10.29333/iji.2019.12440a

Mihailidis, P., \& Cohen, J. N. (2013). Exploring curation as a core competency in digital and media literacy education. Faculty Works: Digital Humanities \& New Media, 4, 1-20.

Muhid, A., Amalia, E. R., Hilaliyah, H., Nia, B., \& Wajdi, M. B. N. (2020). The effect of metacognitive strategies implementation on students' reading comprehension achievement. International Journal of Instruction, 13(2), 847-862. https://doi.org/10.29333/iji.2020.13257a

Nakayama, M., Yamamoto, H., \& Santiago, R. (2007). The impact of learner characterises on learning performance in hybrid courses among Japanese students. Electronic Journal E-Learning, 5(3).195-206. https://files.eric.ed.gov/fulltext/EJ1098825.pdf

Oxford, R. L. (2003). Language learning styles and strategies: an overview. In J. van Kampen \& S. Baauw (Eds.), Proceedings of GALA 2003 (Generative Approaches to Language Acquisition) Conference, (pp. 1-25). Netherlands Graduate School of Linguistics.

Oxford, R. L. (2011). Teaching and researching language learning strategies. Pearson Education Limited.

Rahimi, M., \& Katal, M. (2013). The impact of meta-cognitive instruction on EFL learners' listening comprehension and oral language proficiency. The Journal of Teaching Language Skills, 5(2), 69-90. https://doi.org/10.22099/JTLS.2013.1555

Rahimirad, M., \& Shams, M. R. (2015). The effect of activating meta-cognitive strategies on the listening performance and meta-cognitive awareness of EFL students. The International Journal of Listening, 28(3), 162-176. https://doi.org/10.1080/10904018.2014.902315.

Reid, J. (1995a). Learning styles in the ESL/EFL classroom. Heinle \& Heinle Publishers.

Reid, J. (1995b). The learning style preferences of ESL students. TESOL Quarterly, 21(1), 87-103. https://doi.org/10.2307/3586356

Reza, M. A., Zeraatpishe, M., \& Faravani, A. (2019). A path analysis of typical intellectual engagement, learning style and preference for assessment. International Journal of Instruction, 12(1), 1239-1250. https://doi.org/10.29333/iji.2019.12179a

Ruiz-Funes, M. (2015). Exploring the potential of second/foreign language writing for language learning: The effects of task factors and learner variables. Journal of Second Language Writing, 28(6), 1-19. https://doi.org/10.1016/j. jslw.2015.02.001 
Sahragard, R., \& Mallahi, O. (2014). Relationship between Iranian EFL learners' language learning styles, writing proficiency and self-assessment. International Conference on Current Trends in ELT, Procedia-Social and Behavioural Sciences, 98(2014), 1611-1620. https://doi.org/10.1016/j.sbspro.2014.03.585

Santovec, M. (2002). Balancing act: Online learning becomes the "third shift" for women. Distance Education Report, $\quad 6(2), \quad 1-2$. https://doi.org/10.1016/j.sbspro.2014.05.236

Shaughnessy, M. F. (1998). An interview with Rita Dunn about learning styles. Clearing House Journal, 71(3), 20-22. https://doi.org/10.1080/00098659809599346

Smidt, E., \& Hegelheimer, V. (2004). Effects of online academic lectures on ESL listening comprehension, incidental vocabulary acquisition, and strategy use. Computer Assisted Language Learning, 17(5), 517-556. https://doi.org/517556.10.1080/0958822042000319692

Soomro, K. A., Kale, U., Curtis, R., Akcaoglu, M., \& Bernstein, M. (2018). Motivation to Use ICT for Teaching Scale [Database record]. Retrieved from PsycTESTS. https://dx.doi.org/10.1037/t73211-000

Soomro, K. A., Kale, U. Curtis, R., Akcaoglu, M., \& Bernstein, M. (2018). Development of an instrument to measure faculty's information and communication technology access (FICTA). Education and Information Technologies, 23(1), 253-269. https://dx.doi.org/10.1007/s10639-017-9599-9

Soureshjani, K. H., \& Naseri, N. (2012). Perceptual learning-style preferences of Iranian EFL learners in relation to their proficiency level. American Journal of Linguistics, 1(4), 70-74. https://doi.org/10.5923/j.linguistics.20120104.01

Stebbins, C. (1995). Culture-specific perceptual - learning - style preferences of post secondary students of English as a second language. In J. M. Reid (Ed.), Learning styles in the ESL/EFL classroom (pp. 108-117). Heinle \& Heinle Publishers.

Sugiyono, S. (2010). Metode penelitian pendidikan pendekatan kuantitatif, kualitatif, dan $R \& D$. [Educational research methods with quantitative, qualitative, and $R \& D$ approaches]. Alfabeta.

Tisdell, E. (2008). Critical media literacy and transformative learning. Drawing on pop culture and entertainment media in teaching for media diversity in adult higher education. Journal of Transformative Education, 6(1), 48-67. https://doi.org/10.1177/1541344608318970

Tutunis, B. T. (2001). Awareness raising on learner's listening strategies and impact on listening performance. ERIC ED462011.

Vandergrift, L. (1999). Facilitating second language listening comprehension: Acquiring successful strategies. ELT Journal, 53(3), 168-176. https://doi.org/10.1093/elt/53.3.168

Vandergrift, L. (2003). Orchestrating strategy use: Toward a model of the skilled second language listener. Language Learning, 53(3), 463-496. https://doi.org/10.1111/14679922.00232 
Vandergrift, L., Goh, C., Mareschal, C., \& Tafaghodtari, M. H. (2006). The Metacognitive awareness listening questionnaire: Development and validation. Language Learning: A Journal of Research in Language Studies, 56(3), 431-462. https://doi.org/10.1111/j.1467-9922.2006.00373.x

Vandergrift, L., \& Goh, C. C. M. (2012). Teaching and learning second language listening: Metacognition in action. Routledge.

Vandergrift, L., \& Tafaghodtari, M. H. (2010). Teaching L2 learners how to listen does make a difference: An empirical study. Language Learning, Language Learning: A Journal of Research in Language Studies, 60(2), 470-497. https://doi.org/10.1111/j.1467-9922.2009.00559.x

Vandergrift, L., Goh, C. C. M., Mareschal, C. J., \& Tafaghodtari, M. H. (2006). The meta-cognitive awareness listening questionnaire: Development and validation. Language Learning, 56(3), 431-462. https://doi.org/10.1111/j.1467-9922.2006.00373.x

Vandergrift, L., Goh, C., Mareschal, C. J., \& Tafaghodtari, M. H. (2006). The metacognitive awareness listening questionnaire: Development and validation. Language Learning, 56(3), 431-462. https://doi.org/10.1111/j.14679922.2006.00373.x

Waldeck, J., Kearney, P., \& Plax, T. (2001). Teacher e-mail message strategies and students' willingness to communicate online. Journal of Applied Communication Research, 29(1), 54-70. https://doi.org/10.1080/00909880128099

Wehrwein, E. A., Lujan, H. L. \& DiCarlo, S. E. (2006) Gender differences in learning style preferences among undergraduate physiology students. Advances in Physiology Education, 31(6), 153-157, 2007. https://doi.org/10.1152/advan.00060.2006.

Wenden, A. (1998). Meta-cognitive knowledge and language learning. Applied Linguistics, 19(4), 515-537. https://doi.org/10.1093/applin/19.4.515

Yazon, A. D., Ang-Manaig, K., Buama, C. A., \& Tesoro, J. F. (2019). Digital literacy, digital competence and research productivity of educators. Self-Assessment Tool of the European Digital Competence Framework for Educators (DigComEdu). Universal Journal of Educational Research, 7(8), 1734-1743. https://doi.org/10.13189/ujer.2019.070812.

Yu, B., Kim, K., \& Roh, S. (2001). A user analysis for web-based distance education.

Proceedings of the annual topics on distance learning conference, USA. Retrieved February 18, 2002, from http://www.calumet.purdue.edu/todl/proceedings

Zacharis, N. Z. (2011). The effect of learning style on preference for web-based courses and learning outcomes. British Journal of Educational Technology, 42(5), 790-800. https://doi.org/10.1111/j.1467-8535.2010.01104.x

Zapalska, A., \& Brozik, D. (2015). Learning styles and online education. Campus-Wide Information Systems, 23(5), 325-335. https://doi.org/1108/10650740610714080

Zarrabi, F. (2017). Investigating the relationship between learning style and metacognitive listening awareness. International Journal of Listening, 34(1), 1-13. https://doi.org/10.1080/10904018.2016.1276458 